\title{
PERAN MAKSUD DIDALAM DISONANSI KOGNITIF PESERTA PELATIHAN VOKASIONAL RENCANA USAHA DAN MANAJEMEN KEUANGAN KSM BINAAN BDC SRIWIJAYA PALEMBANG
}

\author{
Ellys $^{1}$, Lily Rahmawati Harahap ${ }^{2}$, R.Y.Effendi ${ }^{3}$
}

${ }^{1}$ Universitas IBA, Palembang, Indonesia, ellysthoyib@ gmail.com
2Universitas IBA, Palembang, Indonesia, harahaplily@ gmail.com
${ }^{3}$ Universitas IBA, Palembang, Indonesia, effendiry@ gmail.com

\begin{abstract}
This study aims to determine the role of intention in cognitive dissonance among 70 participants in vocational training on business plan and financial management of micro small entrepreneurs in independent community groups (KSM) producers of pempek, kemplang kerupuk, jumputan, tajung, blongket and songket. The hope is to change the mindset of participants in traditional financial management into accountable financial management. This knowledge is a stimulus that will stimulate the intention, to be a strong predictor of forming attitudes and expected behavior. It turns out that after 4 months of training, only $5 \%$ of the participants implemented this material, while $95 \%$ did not. The results of the study of the authors obtained data that the positive intention in the cognitive system of participants is very high, ranging from $74 \%$ to $97 \%$. There has been a cognitive dissonance in the participants' attitudes and behavior. So it can be concluded that positive intentions can be in line with attitudes and behaviors but may not, this can happen because there is no strong role from external elements, such as limited market prospects and channeling around them, capital and financial management have not been effective, quality of management and $H R$ is not yet committed, the role of BDC as a coach is not optimal, it should be able to play an active role as the foster father of KSM.
\end{abstract}

Keyword : Intention, Cognitive, Dissonance

\section{PENDAHULUAN}

Mengelola usaha kecil mikro adalah pekerjaan yang paling mudah dilakukan masyarakat karena cukup dengan keterampilan tertentu dan modal seadanya mereka dapat menghasilkan pendapatan. Namun dengan kondisi ini usaha kecil mikro sulit berkembang bahkan tidak sedikit yang gulung tikar. Usaha kecil mikro termasuk kedalam kelompok UMKM, yaitu usaha menengah kecil mikro. Sampai saat ini daya 
saing UMKM Indonesia masih rendah bila dibandingkan dengan negara-negara ASEAN lainnya. Rendahnya daya saing tersebut dipengaruhi oleh faktor internal dan eksternal. Faktor internal antara lain kemampuan SDM yang rendah, strategi pemasaran minim inovasi dan penggunaan tehnologi komunikasi dan informasi belum efektif. Sedangkan faktor eksternal disebabkan oleh akses finansial dan permodalan, infrastruktur serta kondisi ekonomi makro. Data BPS menunjukkan bahwa pertumbuhan UMKM dari Januari 2018 ke Juni 2019 hanya 11,48\% ( (BPS, 2019). Padahal Pemerintah berkomitmen untuk memajukan UMKM agar terus berkembang menjadi usaha menengah dan usaha besar atau mencapai tingkat pertumbuhan yang lebih tinggi lagi. Kemampuan sumberdaya manusia yang kompeten, terampil dan kreatif sangat dibutuhkan untuk memajukan UMKM diantaranya dibidang produksi dan kualitas produk, pemasaran, keuangan dan sumberdaya manusia.

Berbagai pelatihan keterampilan sudah diupayakan oleh Pemerintah dalam rangka meningkatkan kompetensi sumberdaya manusia bagi pelaku usaha kecil mikro, seperti pelatihan standarisasi kualitas produk, pemasaran on-line, kewirausahaan dan pelatihan vokasional rencana usaha dan manajemen keuangan. Pada bulan Desember 2018 telah dilakukan kegiatan pelatihan vokasional untuk pelaku usaha kecil mikro dalam Program KOTAKU Kementerian PUPR. Pelaku usaha kecil mikro yang mendapatkan pelatihan ini adalah usaha kecil mikro produk unggulan lokal yang tergabung didalam kelompok swadaya masyarakat (KSM) binaan BDC Sriwijaya Palembang. LPAM Fakultas Ekonomi UIBA mendapat kepercayaan untuk menjadi provider yang melaksanakan pelatihan manajemen keuangan usaha kecil. Pelatihan ini dimaksudkan untuk meningkatkan kemampuan pengelolaan keuangan kelompok usaha kecil mikro yang memproduksi produk seperti pempek, kemplang kerupuk, kain tenun songket, blongsong, jumputan dan songket yang menjadi produk unggulan lokal Sumatera Selatan. Kompetensi yang diharapkan dari pelatihan ini adalah pelaku usaha mampu mencatat setiap transaksi keuangan kedalam buku pembelian, penjualan, Kas, Bank, piutang dan utang. Melalui data-data keuangan yang dicatat dalam buku-buku tersebut dapat diketahui apakah usaha yang dilakukan mendapatkan laba atau rugi, bagaimana perputaran modal usaha dan bagaimana perbandingan piutang dan utang. Diharapkan dari pelatihan ini mereka mampu mengelola keuangan usaha dengan baik dan dapat 
menyusun rencana pengembangan usaha sehingga dapat memanfaatkan akses finansial dan permodalan yang ditawarkan oleh Pemerintah atau lembaga swasta bahkan kerjasama dengan investor. Dengan kemampuan ini pelaku usaha kecil akan terbiasa melakukan pencatatan setiap transaksi keuangan usaha dengan baik.

Setelah mendapat pelatihan selama 2 hari, 2 minggu kemudian dilakukan monitoring untuk mengetahui apakah semua peserta sudah memahami dan mampu melakukan pencatatan setiap transaksi keuangan ?, ternyata tidak satupun peserta yang melakukan pencatatan keuangannya. 4 bulan berikutnya penulis melakukan monitoring kembali kepada peserta untuk memastikan apakah KSM melakukan pencatatan keuangan atau tidak, ternyata hanya 5\% yang melakukan pencatatan, sedangkan $95 \%$ tidak melakukan. Berbagai alasan yang mereka kemukakan dan umumnya mereka lebih suka mengingat saja. Fenomena ini menunjukkan kemungkinan adanya ketidaksesuaian antara dua sikap atau lebih atau antara sikap dan perilaku, dalam teori Leon Festinger disebut dengan disonansi kognitif. (Kinichi, 2014). Untuk memahami kemungkinan ini penulis melakukan beberapa tahapan analisis yaitu ; analisis pertama telah dilakukan dengan mengukur trend nilai jawaban pre-test dan post-test peserta, hasilnya adalah menunjukkan trend nilai jawaban peserta yang meningkat dari pre-test ke post-test sebesar $73 \%$, trend menurun $17 \%$ dan yang turun naik atau ragu-ragu 10\%. (Ellys., 2019). Berikut grafiknya ;

\section{Grafik 1}

Trend Nilai Jawaban Peserta Pelatihan Vokasional untuk Materi Rencana Usaha dan Manajemen Keuangan

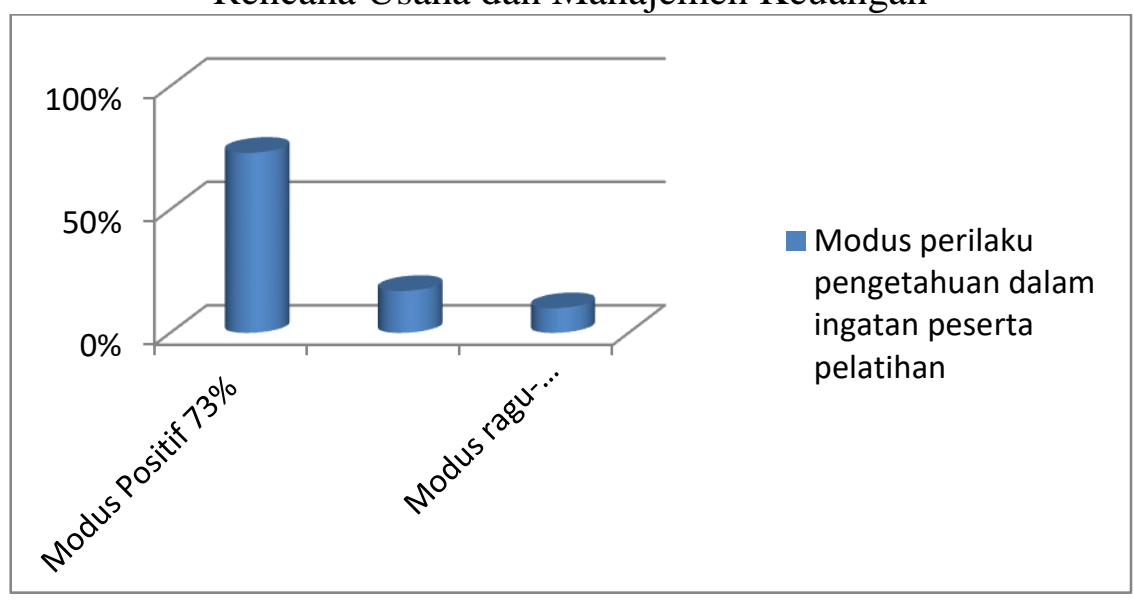

Sumber : Ellys., 2019 
Trend nilai jawaban ini penulis beri nama sebagai modus perilaku pengetahuan dalam ingatan. Hasil ini menggambarkan bahwa kemampuan peserta memahami materi rencana usaha dan manajemen keuangan cukup baik, dimana dengan nilai jawaban peserta dari pre-test ke post-test secara umum ada perubahan yang cenderung meningkat, walaupun ada yang menurun dan naik turun atau ragu-ragu. Analisis kedua, penulis mencoba untuk mengetahui bagaimana tanggapan kognitif peserta setelah merespon stimulus materi rencana usaha dan manajemen keuangan. Tanggapan kognitif ini berupa pemikiran atau kognisi yang ada didalam logika berfikir peserta. Untuk mendapatkan informasi tersebut diajukan sebuah pernyataan sebagai berikut ; "Saya percaya mampu memahami materi rencana usaha dan manajemen keuangan ". Ada 2 jenis kognisi yang dapat muncul didalam pemikiran peserta yaitu kognisi positif atau negatif. Hasil dari jajak pendapat tersebut $83 \%$ peserta berfikir positif atau kognisi positif yang berarti bahwa mereka percaya memiliki kemampuan memahami kedua materi. Sedangkan 17\% peserta menganggapi negatif dimana mereka kurang percaya mampu memahami kedua materi. (Ellys., 2019). Berikut informasi besar persentase kognisi positif dan negatif yang muncul ;

Grafik 2

Persentase Kognisi Positif dan Negatif dalam Struktur Kognitif

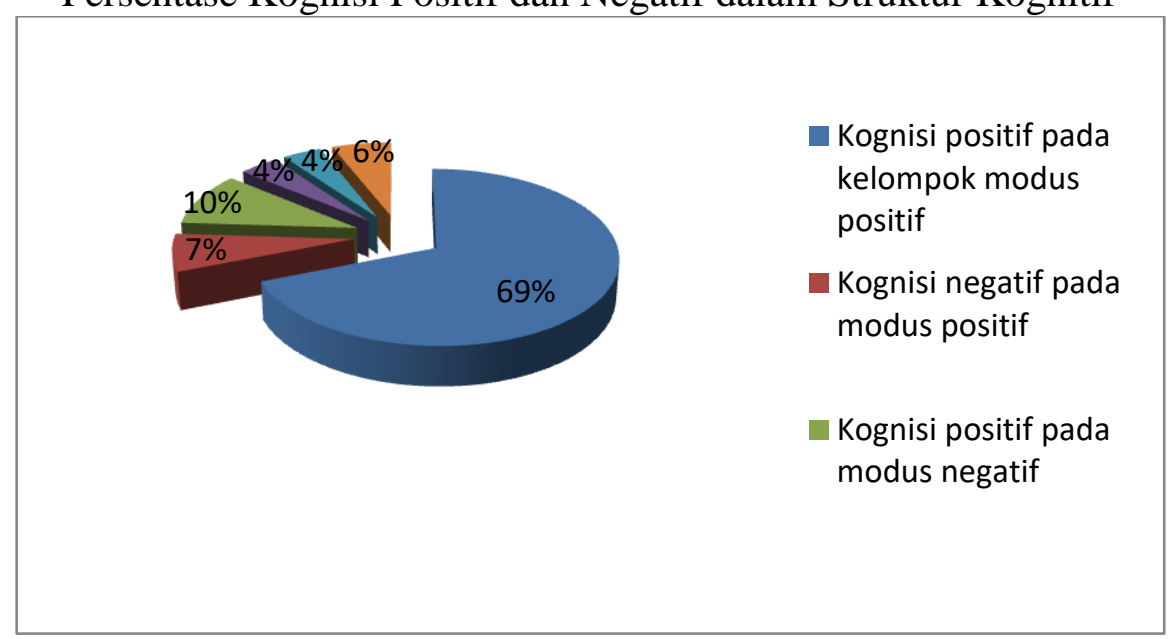

Sumber : Ellys., 2019

Dari data diatas tergambar bahwa sesungguhnya kemampuan berfikir sebagian besar peserta memahami materi dan percaya bahwa mempunyai kemampuan untuk menggunakan materi tersebut kedalam proses pengelolaan keuangan usaha mereka. 
Dalam penelitian yang sama, penulis juga mengalisis tentang peran emosi atau perasaan didalam sistem afektif peserta tentang respon stimulus materi Rencana usaha dan manajemen keuangan, maka diberikan satu pernyataan yaitu ; "Pengetahuan tentang rencana usaha dan manajemen keuangan sudah saya ketahui sebelumnya dan saya rasa sangat penting untuk kemajuan usaha saya, sehingga saya harus menggunakan pengetahuan ini untuk mengelola usaha ". Hasil yang diperoleh $74 \%$ peserta memberikan jawaban kognisi positif dan $26 \%$ kognisi negatif. Telah terjadi perubahan pemikiran atau kognisi dari kognisi positif ke negatif sebesar 9\% yaitu dari $83 \%$ menjadi $74 \%$. Sedangkan peserta yang berfikir negatif meningkat $9 \%$ yaitu dari $17 \%$ menjadi $26 \%$. Berikut grafiknya ;

Grafik 3

Perubahan Kognisi Positif dan Negatif setelah berintegrasi dengan emosi

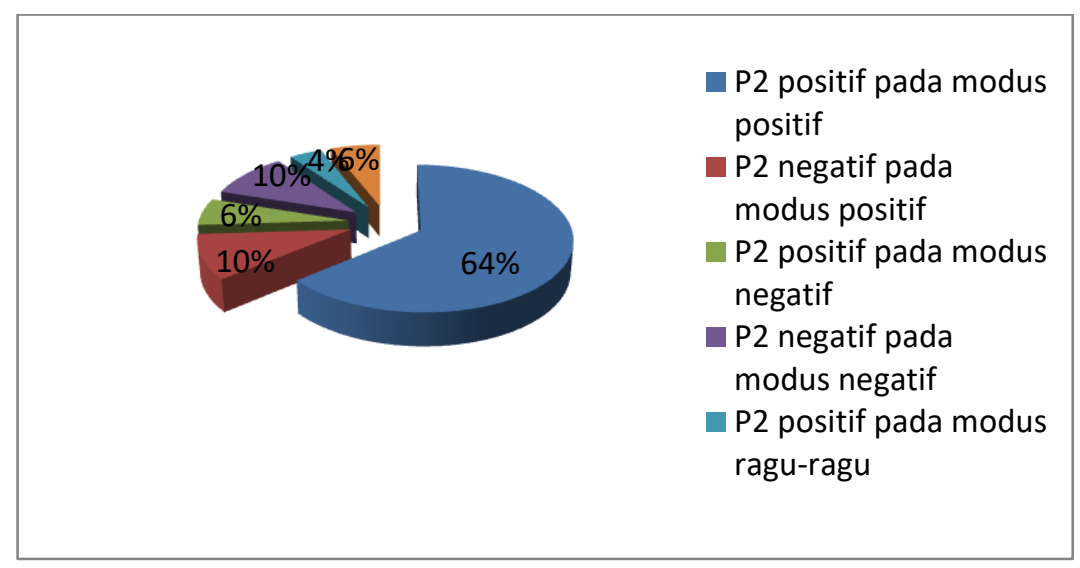

Sumber : Ellys., 2019

Dari grafik diatas menggambarkan bahwa ketika peserta memahami dengan melibatkan perasaan atau emosi, maka tanggapan terhadap materi rencana usaha dan manajemen keuangan menunjukkan kognisi positif semakin turun sebaliknya kognisi negatif meningkat. Kombinasi kognitif dan afektif akan membentuk kecenderungan terpelajar untuk memberikan tanggapan dalam cara yang menyenangkan dan tidak menyenangkan dengan respek terhadap suatu objek disebut sebagai sikap. (Kinichi, 2014). Selanjutnya sikap juga dapat berupa komitmen atau kesetujuan/kesediaan untuk melakukan sesuatu. Untuk memahami sikap peserta, penulis melakukan analisis berikutnya, melalui angket pernyataan "Setelah pelatihan saya bersedia menggunakan pengetahuan rencana 
usaha dan manajemen keuangan sebagai pedoman pencatatan setiap transaksi usaha".

Grafik 4

Informasi Persentase Sikap atau Kesediaan Peserta

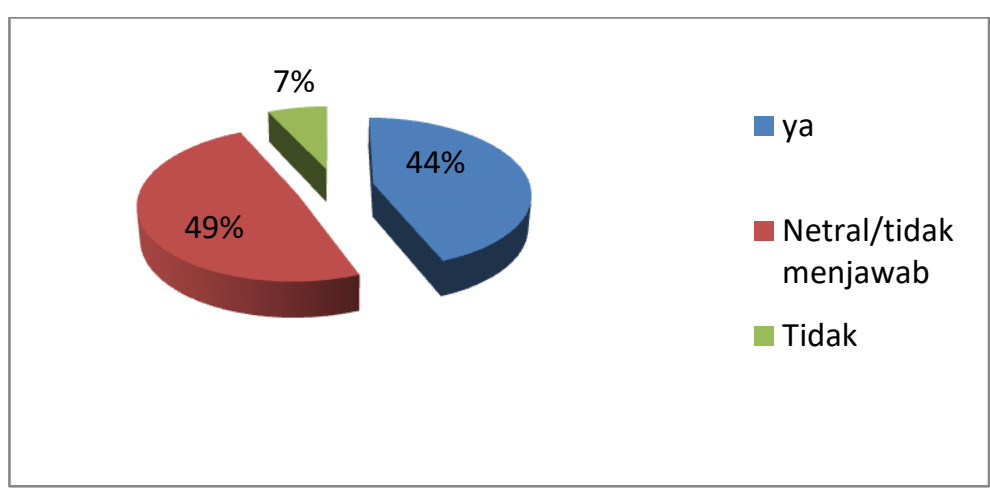

Sumber : Ellys., 2019

Ternyata jawaban peserta sebagai berikut ; sikap yang bersedia 44\%, tidak bersedia $7 \%$ dan netral 49\%. Hasil ini menggambarkan bahwa peserta yang memberikan tanggapan positif dan negatif terhadap materi rencana usaha dan manajemen keuangan, semakin menurun dan beralih kepada jawaban netral atau ragu-ragu atau tidak mau berpendapat. Hal ini menunjukkan bahwa ketika seseorang yang sudah berfikiran positif atau negatif terhadap suatu stimulus bisa saja akan berubah ketika diminta untuk komitmen atau bersedia untuk menggunakan materi ini didalam pengelolaan keuangan usaha. Sikap, juga dapat menjelaskan maksud seseorang untuk berperilaku dalam cara tertentu. (A.Judge, 2015). Selanjutnya dikatakan bahwa sikap dapat terbentuk lebih dari satu dan dapat saja terjadi pertentangan atau ketidaksesuaian diantaranya. Sikap merupakan sekumpulan kepercayaan dan perasaan yang dimiliki seseorang mengenai ide-ide, situasi tertentu, orang atau peristiwa. (Moorhead.Griffin, 2013). Sikap menentukan apa yang akan dilakukan seseorang. Sikap dapat direfleksikan melalui perkataan dari seseorang. Seringkali ada ketidaksesuaian antara dua atau lebih sikap atau antara perilaku dan sikap seseorang. (A.Judge, 2015). Selanjutnya Leon Festinger mengatakan bahwa ketidaksesuaian ini disebut sebagai disonansi kognitif (cognitif dissonance).Disonansi kognitif dapat dikatakan sebagai ketidaksesuaian dari sikap yang dibentuk oleh komponen kognitif dan afektif terhadap perilaku. Icek Ajzen dan Martin Fiesbein mengatakan bahwa ketidaksesuaian antara sikap dan perilaku seseorang didasari oleh 
"maksud" untuk melakukan sebuah perilaku tertentu. (Kinichi, 2014). Selanjutnya Ajzen menjelaskan bahwa ada 3 faktor penentu "maksud" yaitu ; 1. Sikap terhadap perilaku dimana seseorang memiliki evaluasi yang baik atau buruk atau penilaian atas perilaku tersebut, misalnya ketika peserta berfikir positif, kemudian bersikap positif dan berperilaku untuk memanfaatkan materi rencana usaha dan manajemen keuangan didalam pengeloaan keuangan usaha karena peserta memiliki evaluasi atau penilaian yang baik terhadap maksud pelatihan materi tersebut. Dan sebaliknya bila evaluasi buruk terhadap manfaat materi, maka peserta akan berperilaku menolak melakukan pencatatan transaksi keuangan sesuai dengan yang diajarkan. 2. Norma subjektif, berupa tekanan sosial yang dirasakan untuk melakukan atau tidak melakukan perilaku tersebut. Tekanan sosial dari kelompok, misalnya didalam kelompok banyak anggota yang menerapkan materi dalam pengelolaan keuangan, maka yang lain juga akan ikut, sebaliknya bila lebih banyak anggota kelompok tidak melakukan maka yang lain juga mengikuti. 3. Kontrol perilaku yang dirasakan berupa kemudahan atau kesulitan yang dirasakan apabila melakukan perilaku tertentu. Misalnya ketika peserta merasakan kesulitan untuk menerapkan kedua materi karena membutuhkan tambahan waktu dan tenaga. Sementara bila diingat saja lebih mudah. Berikut ilutrasi teori Ajzen tentang paradigma disonansi kognitif melalui faktor penentu "maksud"

Gambar 1

Paradigma Disonansi Kognitif

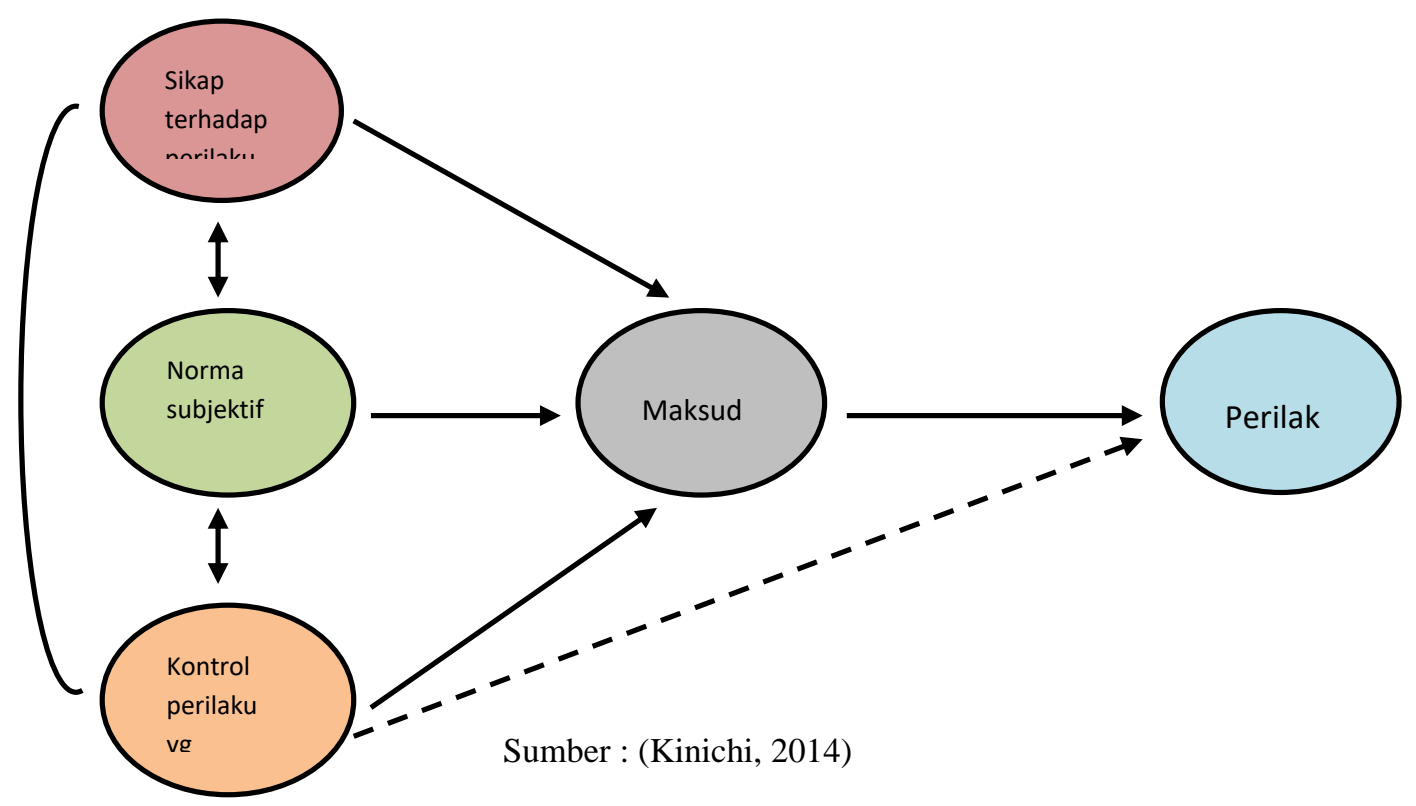


Melalui penelitian ini, penulis mencoba untuk mengetahui apakah ketiga faktor penentu "maksud" tersebut berperan menciptakan ketidaksesuaian antara sikap dan perilaku peserta pelatihan vokasional rencana usaha dan manajemen keuangan kelompok swadaya masyarakat (KSM) binaan BDC Sriwijaya Palembang. Oleh karena itu artikel ini, diberi judul “ Peran Maksud didalam Disonansi Kognitif Peserta Pelatihan Vokasional Rencana Usaha dan Manajemen Keuangan KSM Binaan BDC Sriwijaya Palembang”.

\section{METODOLOGI PENELITIAN}

\section{Objek penelitian}

Untuk mendapatkan informasi yang dibutuhkan, penulis melakukan survey kepada 70 peserta pelatihan vokasional rencana usaha dan manajemen keuangan kelompok swadaya masyarakat (KSM) yang mempunyai usaha kecil mikro bidang produksi kuliner dan tenun khas Palembang. KSM yang dijadikan responden adalah KSM binaan "Business Development Centre" (BDC) Sriwijaya Palembang.

\section{Desain Penelitian}

Analisis pada penelitian ini didesain secara desktiptif kualitatif yaitu mengidentifikasi fenomena psikologis yang berhubungan dengan pemikiran, sikap dan perilaku peserta setelah mendapatkan pelatihan vokasional rencana usaha dan manajemen keuangan. Dinamika fenomena psikologis ini akan di conferm melalui teori-teori yang relevan untuk disajikan sebagai suatu artikel ilmiah yang layak dipahami dan diketahui oleh publik.

\section{Metode Pengumpulan Data}

Data diperoleh melalui pemberian angket pernyataan tertutup kepada peserta pada minggu pertama dan 4 bulan setelah pelatihan. Pilihan jawaban peserta terhadap pernyataan-pernyataan yang diajukan ada 3 yaitu "setuju", "tidak setuju" dan "netral/tidak tahu". Ketiga kelompok pilihan ini dipersentasekan untuk mengetahui besaran dari unsur-unsur yang berperan didalam proses terbentuknya "maksud" didalam disonansi kognitif pada sikap dan perilaku peserta untuk melakukan pengelolaan keuangan berdasarkan tehnik-tehnik rencana usaha dan manajemen keuangan. Data-data kuantitatif ini akan dirujuk melalui teori-teori yang relevan. Ada tiga kelompok 
pernyataan yang diformat sesuai dengan kebutuhan untuk menggali informasi tentang 3 unsur "maksud" atau "kesiapan seseorang untuk melakukan perilaku tertentu", yaitu sikap terhadap perilaku, norma subjektif dan kontrol perilaku yang dirasakan. Pernyataan-pernyataan tersebut adalah sebagai berikut ;

1. Untuk mengetahui tentang unsur sikap terhadap perilaku yaitu mengukur kemampuan evaluasi yang baik atau buruk atau penilaian atas perilaku untuk melakukan pengelolaan keuangan usaha berdasarkan tehnik-tehnik rencana usaha dan manajemen keuangan yang telah diajarkan pada pelatihan vokasional, maka pernyataan yang diajukan adalah ;

a. Pengetahuan tentang rencana usaha dan manajemen keuangan sudah saya ketahui sebelumnya dan saya rasa sangat penting untuk kemajuan usaha saya, sehingga saya harus menggunakan pengetahuan ini untuk mengelola usaha.

b. Saya merasa kesulitan memahami dan menjalankan materi rencana usaha dan manajemen keuangan didalam pengelolaan keuangan usaha karena sudah lupa, maka saya berharap pembimbingan secara konsisten sampai usaha berkembang.

2. Untuk mengetahui tentang unsur norma subjektif yaitu berupa tekanan sosial yang dirasakan untuk melakukan atau tidak melakukan perilaku tersebut. Tekanan sosial disini dapat berupa tekanan karena kebutuhan ekonomi dirinya dan keluarga atau norma-norma agama dan sosial. Ketentuan tertentu dari pihak lain atau ikut-ikutan perilaku dilingkungan kelompok, maka pernyataan yang diajukan adalah ;

a Laporan keuangan dan rencana usaha menjadi persyaratan kepercayaan pihak ketika untuk memberikan pinjaman modal usaha dari pihak ketiga.

b Saya ingin usaha saya semakin berkembang, agar keuntungan meningkat sehingga dapat mnemenuhi kebutuhan fashion yang lebih baik seperti pengusaha sukses lainnya.

3. Untuk mengetahui tentang kontrol perilaku yang dirasakan, maka pernyataan yang diajukan yaitu ;

a. Saya merasa bertanggung jawab pada kemajuan usaha, karena saya ingin anakanak dan keluarga dapat hidup lebih baik 
b. Walaupun saya ini seorang ibu rumah tangga, saya ingin usaha saya semakin berkembang dan menjadi usaha besar, sehingga dapat meningkatkan ekonomi keluarga

Hasil jawaban KSM akan dikelompokkan kepada 3 kelompok yaitu jawaban setuju dan tidak setuju atau tidak menjawab / netral. Ke 3 kelompok ini akan dipersentasekan untuk mengetahui besaran dari unsur sikap, norma subjektif dan kontrol perilaku. Jawaban setuju berarti "maksud positif" lebih kuat untuk bersikap dan berperilaku yang mendukung bahwa mengelola keuangan yang baik akan membantu mewujudkan harapan mereka. Sedangkan bila jawaban tidak setuju berarti "maksud negatif atau menolak" lebih kuat untuk bersikap dan berperilaku yang menolak untuk membiasakan melakukan pencatatan keuangan usaha karena lebih mudah mengingat. Bila tidak menjawab atau tidak tau atau netral berarti tidak ada unsur-unsur maksud yang dapat mendorong sikap atau perilaku. Menurut model perilaku terencana Ajzen (Kinichi, 2014), maksud seseorang untuk melakukan sebuah perilaku tertentu adalah prediktor kuat dari perilaku tersebut. Disinilah akan terjadi disonansi kognitif, dimana ketika seseorang mempunyai maksud dimana maksud itu tidak sama dengan unsur sikap atau kemampuan evaluasi seseorang terhadap sikap maka akan terjadi disonansi kognitif, dimana kemampuan evaluasi seseorang itu biasanya didasari oleh pengetahuan atau pengalaman seseorang. Misalnya seseorang yang pengetahuannya masih sedikit tentang materi rencana usaha dan manajemen keuangan maka dia akan mengalami ketidaksesuaian dengan sikap dan perilaku. Begitu juga bila maksud tersebut karena ada norma-norma subjektif misalnya kewajiban dan tanggungjawab atau karen pertemanan (kelompok), maka hal ini juga dapat menimbulkan disonansi kognitif yaitu ketidaksesuaian sikap misalnya seseorang bersikap dan beperilaku karena kewajiban atau karena ajakan teman. Disonansi kognitif juga dapat terjadi karena unsur kontrol perilaku dimana maksud seseorang itu beriringan dengan kontrol perilaku yang dirasakan, misalnya seorang ibu rumah tangga akan selalu mengontrol perilakunya untuk kebahagiaan keluarga dan anak-anaknya. । 


\section{Metode Analisis}

Data jawaban peserta pelatihan atas pernyataan-pernyataan yang diajukan untuk mengetahui apakah terjadi disonansi kognitif didalam proses adopsi materi rencana usaha dan manajemen didalam pengelolaan keuangan mereka maka penulis menganalisisnya secara disktiptif kualitatif yaitu mempersentasekan jawaban pernyataan peserta yang telah mengandung unsur kemampuan evalusi, norma subjektif dan kontrol perilaku yang dirasakan peserta untuk mengadopsi materi rencana usaha dan manajemen keuangan dan menerapkannya pada pengelolaan keuangan mereka. Kemudian hasil persentase tersebut dianalisis dengan teori-teori yang relevan.

\section{ANALISIS DAN PEMBAHASAN}

\section{Hasil}

Setelah pernyataan-penyataan tertutup yang diberikan kepada peserta untuk mereka centang salah jawaban yang tersedia, maka dipersentasekan besaran pilihan peserta. Dimaksudkan pilihan jawaban itu akan mempresentasikan apakah telah terjadi disonansi kognitif atau tidak pada peserta pelatihan materi rencana usaha dan manajemen keuangan. Presentase tersebut diharapkan dapat menjadi referensi untuk mengetahui ;

1. Bagaimana maksud atau kesiapan peserta untuk melakukan perilaku tertentu yang didasari oleh sikap terhadap perilaku peserta yaitu kemampuan evaluasi terhadap materi rencana usaha dan manajemen keuangan sebagai suatu prediktor kuat atas perilakunya.

2. Bagaimana maksud atau kesiapan peserta untuk melakukan perilaku tertentu yang didasari oleh norma subjektif akan menjadi prediktor kuat atas perilaku peserta setelah pelatihan.

3. Bagaimana maksud atau kesiapan peserta untuk melakukan perilaku tertentu yang didasari kontrol perilaku yang dirasakan, akan menjadi prediktor kuat atas perilaku setelah pelatihan.

Pada gambar-gambar dibawah ini, akan menggambarkan persentase maksud yang mendasari oleh sikap terhadap perilaku, norma subjektif dan kontrol perilaku yang dirasakan sebagai prediktor kuat atas perilaku peserta, sebagai berikut ; 
Grafik 5.

Maksud didasari sikap terhadap perilaku peserta

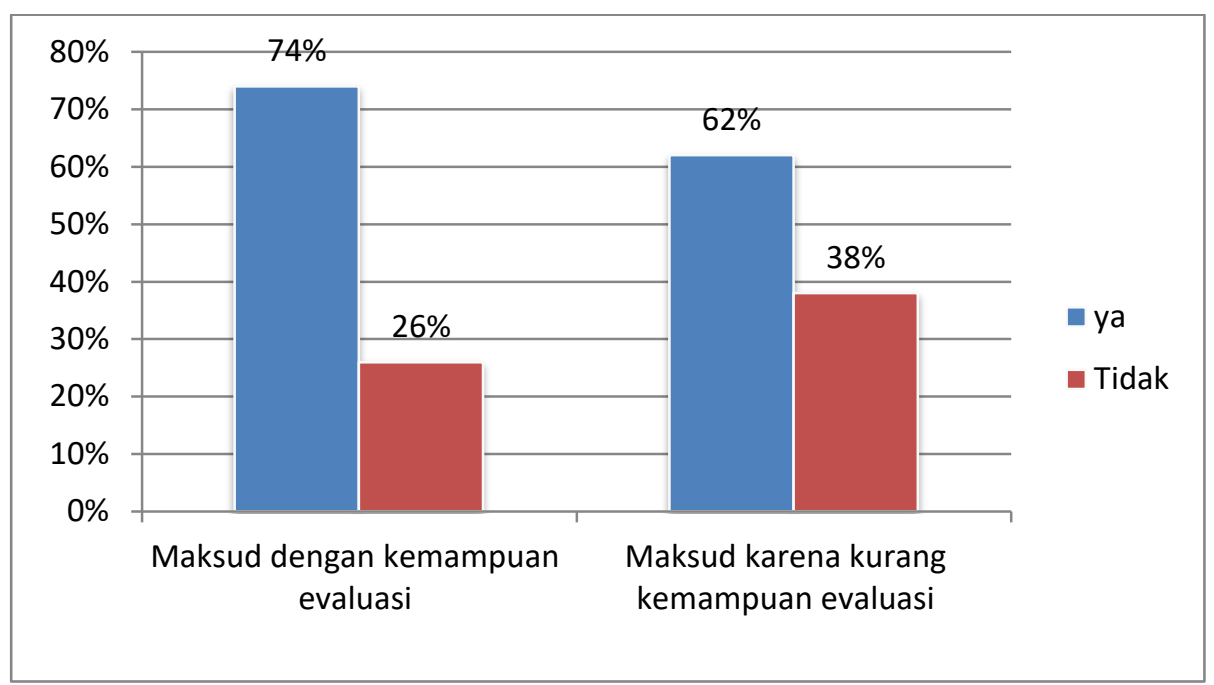

Sumber : Olahan data angket, 2019

Penjelasan ;

1. Maksud atau kesiapan peserta untuk melakukan perilaku tertentu dalam hal ini mengadopsi materi rencana usaha dan manajemen keuangan dan membiasakan mencatat setiap transaksi keuangan kedalam buku kas dan buku-buku pencatatan traksaksi yang lain.

2. Maksud didasari sikap terhadap perilaku yaitu kemampuan evaluasi adalah maksud yang muncul pada sistem kognitif peserta yang pernah mendapat dan memahami materi rencana usaha dan manajemen keuangan. Sedangkan maksud dengan kemampuan evaluasi kurang adalah maksud yang muncul dalam sitem kognitif peserta yang belum pernah mendapat dan memahami materi rencana usaha dan manajemen keuangan atau karena sudah lupa.

3. Maksud dengan kemampuan evaluasi peserta terhadap materi pelatihan hasil angket menunjukkan bahwa $74 \%$ peserta mempunyai maksud setuju atau mengiyakan peserta mempunyai kemampuan evaluasi karena sudah mengetahui materi rencana usaha dan manajemen keuangan, sedangkan maksud tidak setuju 26\%. Sedangkan Peserta dengan kemampuan evaluasi kurang menunjukkan $62 \%$ mempunyai maksud setuju atau mengiyakan, sedangkan maksud tidak setuju atau tidak sebesar $38 \%$. 
Grafik 6

Maksud didasari norma subjektif

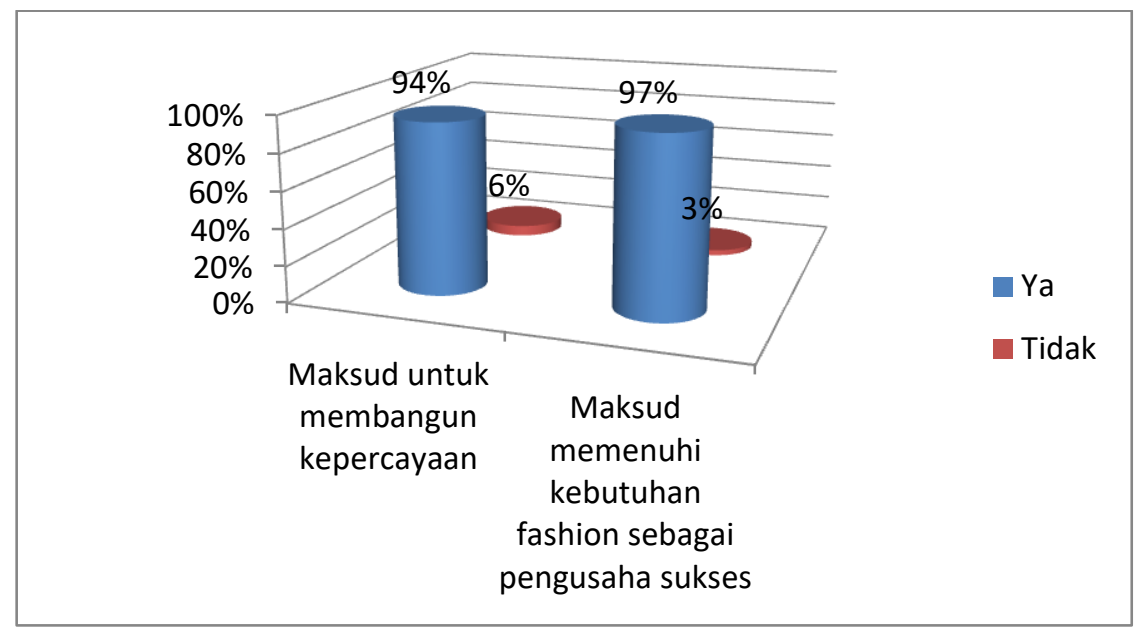

Sumber : Olahan data angket, 2019

1. Maksud untuk membangun kepercayaan, dari hasil angket menunjukkan bahwa $94 \%$ peserta setuju atau mengiyakan untuk mengadopsi materi rencana usaha dan manajemen keuangan kemudian membiasakan mencatat setiap transaksi keuangan kedalam buku kas dan buku-buku pencatatan traksaksi yang lain. Dengan harapan mendapatkan bantuan modal usaha. Sedangkan $6 \%$ menyatakan tidak.

2. Maksud memenuhi kebutuhan fashion sebagai pengusaha sukses. Angket menunjukkan bahwa $97 \%$ peserta setuju atau mengiyakan bahwa materi rencana usaha dan manajemen keuangan sebagai metode untuk mengelolaan keuangan yang baik, sehingga keluar masuk keuangan usaha terkontrol, usaha untung atau rugi dapat diketahui, pelaku usaha dapat memprediksi kemungkinan memenuhi kebutuhan fashion lebih baik. $3 \%$ menjawab tidak.

Grafik 7

Maksud didasari kontrol perilaku yang dirasakan

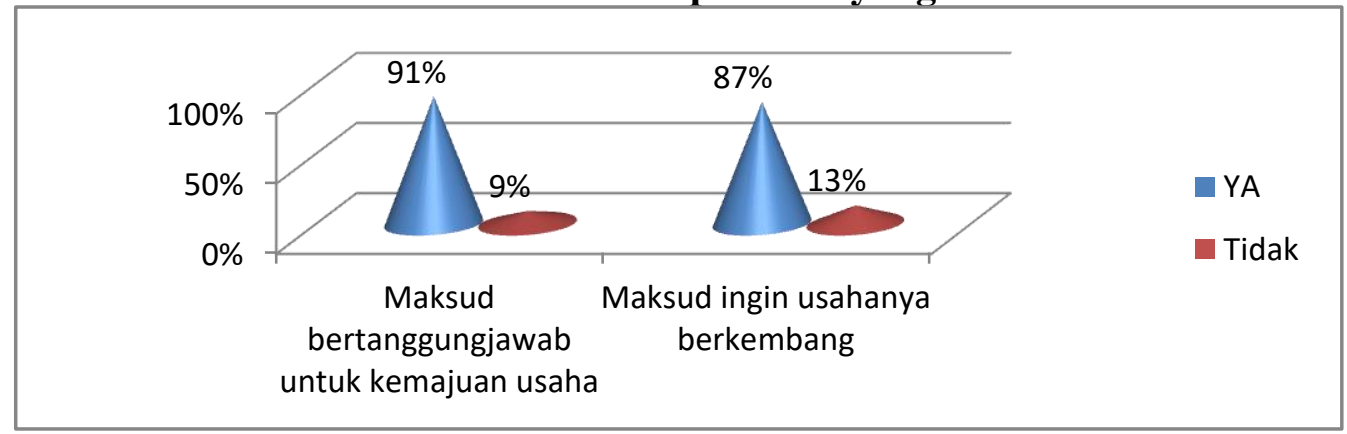

Sumber : Olahan data angket, 2019 
Penjelasan ;

1. Maksud didasari kontrol perilaku yang dirasakan yaitu maksud yang muncul dalam sistem kognitif peserta karena rasa tanggungjawab untuk memajukan usahanya. Hasil angket menunjukkan bahwa $91 \%$ peserta setuju atau mengiyakan bahwa salah satu cara memajukan usaha adalah mengelola keuangan dengan baik dimulai dengan mencatat setiap transaksi keuangan kedalam buku kas dan buku-buku pencatatan traksaksi lainnya. Sedangkan 9\% peserta menyatakan tidak.

2. Maksud didasari kontrol perilaku yang dirasakan dimana maksud disini adalah keinginan peserta memajukan usahanya untuk meningkatkan ekonomi keluarga. Hasil angket menunjukkan bahwa $87 \%$ peserta setuju atau mengiyakan sedangkan peserta yang menyatakan tidak $13 \%$.

\section{Analisis}

Maksud dapat juga disebut sebagai motif yaitu perangsang keinginan (wants) atau daya penggerak kemauan seseorang bekerja/berusaha. Setiap motif mempunyai tujuan tertentu yang ingin dicapai (S.P.Hasibuan, 2010). Maksud yang sejalan dengan sikap dan perilaku akan menimbulkan kenyamanan atau ketentraman didalam diri psikologis seseorang. Namun bila terjadi ketidaksesuaian maka akan menimbulkan ketidaknyamanan atau disonansi kognitif. Bagaimana disonansi kognitif dapat terjadi ketika maksud peserta untuk memajukan usahanya salah satunya dengan cara membiasakan melakukan pencatatan setiap transaksi keuangan kedalam buku kas dan buku-buku pencatatan lainnya. Pencatatan transaksi keuangan untuk mengontrol arus keluar masuk uang, sehingga pelaku usaha dapat mengetahui apakah usahanya untung atau rugi. Kalau untung berarti harus ada alokasi dana untuk pemupukan modal, kalau rugi berarti harus menyusun langkah-langkah evaluasi dan koreksi.

Analisis disonansi kognitif pada grafik 5;

Kemampuan evaluasi peserta seperti yang dijelaskan pada kalimat diatas, merupakan sikap terhadap perilaku yang didasari maksud peserta. Pada grafik 5 menunjukkan bahwa maksud positif peserta yaitu mengadopsi dan membiasakan melakukan pencatatan keuangan usaha sangat tinggi yaitu $74 \%$ ini berarti bahwa sikap terhadap perilaku atau kemampuan evaluasi terhadap manfaat materi rencana usaha dan manajemen keuangan 
cukup baik. Ternyata mereka ini merupakan peserta berijazah SMA dan SMK berjumlah 56 orang (80\%). Begitu juga peserta yang mempunyai kemampuan evaluasi kurang yaitu $62 \%$. Namun kenyataannya setelah pelatihan, hanya 5\% saja peserta yang melakukan pencatatan transaksi keuangan, sehingga dapat disimpulkan bahwa telah terjadi disonansi kognitif dimana maksud yang kuat namun tidak diikuti oleh sikap dan perilaku yang sejalan.

Analisis disonansi kognitif pada grafik 6 ;

Maksud yang didasari norma-norma subjektif dimana maksud untuk mengadopsi dan membiasakan melakukan pencatatan keuangan usaha karena untuk membangun kepercayaan pihak luar juga tinggi yaitu 94\% dan 97\%. Namun yang mengadopsi hanya $5 \%$, berarti telah terjadi disonansi kognitif pada sikap dan perilaku peserta.

Analisis disonansi kognitif pada grafik 7 ;

Sejalan dengan maksud sebelumnya, maksud yang didasari atas kontrol perilaku yang dirasakan juga menunjukkan maksud positif yang tinggi yaitu $91 \%$ dan $87 \%$ peserta yang menginginkan usaha mereka maju dan berkembang dengan pengelolaan keuangan yang baik. Ternyata maksud tersebut hanya tersimpan saja didalam sistem kognitif karena sikap dan perilaku mereka tidak sejalan dengan maksud.

\section{KESIMPULAN}

1. Pelatihan vokasional rencana usaha dan manajemen keuangan bagi KSM binaan BDC Sriwijaya adalah upaya untuk merangsang munculnya maksud positif untuk pengelolaan keuangan usaha KSM.

2. Maksud positif itu sudah terangsang namun maksud belum menjadi prediktor yang kuat untuk mendorong sikap dan perilaku yang sejalan. Sehingga dapat dikatakan telah terjadi disonansi kognitif pada peserta pelatihan vokasional rencana usaha dan manajemen keuangan.

3. Maksud positif dapat sejalan dengan sikap dan perilaku namun dapat juga tidak, hal ini bisa saja karena belum ada peran yang kuat dari unsur eksternal, misalnya prospek pasar chanelling terbatas sekitar mereka, permodalan dan pengelolaan keuangan belum efektif, kualitas manajemen dan SDM belum komitmen, peran BDC 
sebagai pembina tidak optimal yang seharusnya dapat berperan aktif sebagai bapak angkat para KSM.

\section{REFERENSI}

A.Judge, S. P. (2015). Perilaku Organisasi. Jakarta: Salemba Empat.

BPS. (2019). Biro Pusat Statistik. Jakarta: http://bps.go.id.

Ellys, .. (2018). Analisis Perilaku Pengetahuan dalam Ingatan melalui Jawaban Pre-test,

Post-test dan Monitoring I-II Peserta Pelatihan Vokasional Rencana Usaha dan

Manajemen Keuangan KSM Binaan BDC Sriwijaya “ . Jemasi, 37.

Ellys., R. (2019). Analisis Kognitif Peserta Pelatihan Vokasional Rencana Usaha dan Manajemen Keuangan KSM Binaan BDC Sriwijaya”. Jemasi Vol.15 No1 , 01.

Kinichi, V. G. (2014). Perilaku Organisasi. Jakarta: Salemba Empat.

Moorhead.Griffin. (2013). Perilaku Organisasi. manajemen Sumberdaya Manusia dan organisasi. Jakarta: Salemba Empat.

S.P.Hasibuan, M. (2010). Manajemen Sumberdaya Manusia. Jakarta: Sinar Grafika Offset. 